\title{
THESES
}

\section{SLEEP PATTERNS AND DISORDERS IN ADULTS OF THE RURAL AND ISOLATED BLACK COMMUNITY OF FURNAS DO DIONÍSIO, MS (ABSTRACT)*. THESIS. SÃO PAULO, 2000.}

\author{
RUBENS REIMÃO**
}

The purpose of this research was to verify sleep disorder events in the population of Furnas do Dionísio, State of Mato Grosso do Sul (MS), Brazil . This population of that rural and isolated black community, in the Municipality of Jaraguari, MS, has been assessed. Interviews made in the period of January 1999 to January 2000 have been used. Census-type sampling has been used, assessing all community inhabitants, with age of 18 or more years (Furnas Group), in a total of 120 subjects. The Control Group has been collected in a neighboring rural zone, in the same Municipality, also using Census-type sampling and the same age range, in a total 101 subjects. Populations have been compared in relation to age and gender. Furnas Group was composed by $97.5 \%$ of non-white people and the Control Group by $3.9 \%$ of non-white people $(p=0.001)$.

The instruments used were the following: (a) Giglio adult sleep questionnaire (Giglio questionnaire); (b) Hamilton Depression Rating Scale; (c) CAGE scale, to assess the alcoholism behavior. In conclusion, the usual pattern of night sleep in Furnas Group showed a trend to have sleeping and wakening times earlier than those described in urban populations. Furnas Group sleeping times in the weekends, and wakening times, both in the weekdays and in the weekends, later than those of the Control Group. The usual standard diurnal sleep, in Furnas Group, showed a prevalence of regular siesta, similar to that observed in the Control Group. Both groups have siesta culture, since $66.3 \%$ of the Furnas Group and $59.4 \%$ of the Control Group regularly sleep during daytime.

The events presented at the research time verified when comparing Furnas Group with the Control Group, evidence the following sleep disorders, with higher access of Furnas Group: wish to change the sleeping habits; dissatisfaction with the sleeping place; complaints of sleeping problems; difficulty in falling asleep; irresistible diurnal sleep; sleepwalking; swallowing difficulty and suffocation during sleep; asthma crisis during sleep; sleep paralysis; nightmare; current insomnia. None of the sleep disorders have been found more in the Control Group than in the Furnas Group, in a statistically significant manner. Notwithstanding the differences of sleep impairment between groups, the search for consultation and use of sleeping medication has been similar. Among the assessed diseases, hypertension has been found more in Furnas Group than in the Control Group.

The prevalence of insomnia was largest in the Furnas Group (40.83\%) in comparison with the Control Group (16.83\%); such prevalence has been calculated based on the last week. The event of current insomnia in the Furnas Group showed to be directly related to the following sleep disorders: subjects with insomnia are older than those without insomnia; wish to change sleeping habits; complaints of sleep disorders; difficulty in falling asleep; wakening for many times during the night; earlier wakening at the end of the night; headache during sleep; nightmare. In Furnas Group, the search for care of sleep disorder and use of sleeping medication was similar among subjects with current insomnia and those without current insomnia. In the Control Group, the occurrence of current insomnia has been shown to be directly related to the following sleep complaints: wish to change sleeping habits; complaints of sleep disorders; difficulty in falling asleep; earlier wakening at the end of the night; excessive daytime sleepiness; asthma during sleep; tachycardia during sleep; headache during sleep; nightmare; cramp during sleep; to fall asleep earlier both in the week days and in the weekends. In the Control Group, the search for care of sleep disorders, use of sleeping medication and hypertension has been directly related to current insomnia.

The occurrence of previous insomnia in the Furnas Group showed to be directly related to the following sleep complaints: subjects with severe insomnia were older than those without insomnia; wish to change sleeping habits; wish to increase sleep duration; dissatisfaction with the sleeping place; episodes of irresistible sleep during daytime; excessive daytime sleepiness; sleepwalking; nightmare; current insomnia. In the Furnas Group, the search for care of sleep disorders and the use of sleeping medica- 
tion was similar among those with previous insomnia and those without previous insomnia. In the Control Group, the occurrence of previous insomnia showed to be directly related to the following sleep alterations: subjects with severe insomnia were older than those without insomnia; wish to change sleeping habits; complaints of sleep disorders; episodes of irresistible sleep during daytime; excessive daytime sleepiness; swallowing difficulty, with suffocation feeling during sleep; tachycardia during sleep; presence of current insomnia. In the Control Group, the search for care of sleep disorders, the use of sleeping medications and the presence of hypertension were higher in the subjects with previous insomnia than in those without previous insomnia.

The study of the occurrence of current insomnia both in the Furnas Group and in the Control Group, showed direct correlation between the presence of current insomnia and the severity of the depression indexes, using the Hamilton Depression Rating Scale as instrument. The study of occurrence of previous insomnia both in the Furnas Group and in the Control Group showed direct correlation between the presence of previous insomnia and severity of the depression indexes, using the Hamilton Depression Rating Scale as instrument.

The occurrence of current insomnia in the Furnas
Group showed to be directly related to the abuse of alcohol, using CAGE scale as instrument, which relation is not statistically significant. In the Control Group, the indexes of abuse of alcohol by the CAGE scale were similar in the subjects with current insomnia, in comparison with those without current insomnia. The occurrence of previous insomnia in the Furnas Group showed direct correlation between the severity of insomnia and the abuse of alcohol, using CAGE scale as instrument. In the Control Group, there was tendency to direct correlation between previous insomnia and abuse of alcohol using the CAGE scale, but the correlation had not been statistically significant.

In conclusion, Furnas Group evidenced to be more affected by sleep disorders than the Control Group. The prevalence of insomnia was larger in Furnas Group. Although being more affected, subjects with insomnia in the Furnas Group did not present search for consultation or for use of hypnotic medication. In both groups, current insomnia and previous insomnia were directly related to higher depression indexes. In Furnas Group, insomnia was also associated to abuse of alcohol.

KEY WORDS: sleep habits, sleep disorders, Black isolated rural community, Furnas do Dionísio MS Brazil.

*Padrões e distúrbios do sono em adultos da comunidade negra rural e isolada de Furnas do Dionísio, MS (Resumo). Tese de LivreDocência, Departamento de Neurologia (Disciplina de Neurologia Infantil) da Faculdade de Medicina da Universidade de São Paulo.

**Address: Rua das Glicíneas 128, 04048-050 São Paulo SP, Brasil.

\begin{abstract}
NEUROBIOLOGY AND PHENOMENOLOGY OF DISTURBANCES OF SELF-CONSCIOUSNESS IN FRONTOTEMPORAL DEMENTIA AND ALZHEIMER'S DISEASE (ABSTRACT)*. THESIS. SÃO PAULO, 2000.
\end{abstract}

\title{
LEONARDO CAIXETA**
}

Consciousness, previously an exclusive philosophical matter, has awaked more and more psychopathologists and neuroscientists interested in the phenomenology of its disorders and in the associated neurobiological substrate. Degenerative brain process may represent an important resourse of discoveries in this field, since they can show self-consciousness disorders with a relatively well defined neuroanatomical basis, making easy the relationship between clinics and neurobiology.

Twenty patients with frontotemporal dementia
(FTD) and 22 with Alzheimer's disease (AD) were evaluated in two dimentions of self-consciousness: insight and Theory of Mind. Cognitive, functional, psychopathological and neuroimaging (SPECT scans) measures were statisticaly analysed in association with measures of insight and Theory of Mind, making use of univariate analysis, Fisher Exact Test, student test. Insight and Theory of Mind deficits were invariably important and frequent in FTD, but more mild and variable in AD.

Insight and Theory of Mind deficits showed as- 
sociation with frontal damage. Insight was significantly associated with some variables (severity of ilness, functional adaptation, negative symptoms), but not with others (sex, age, duration of ilness, years of education) in a general form for FTD and AD groups. Mirror sign, phenomenum that indicates the presence of a severe Theory of Mind deficit, was observed in $40 \%$ of the FTD group and in $31,8 \%$ of the $A D$ group and it was associated with the presence of confabulations, severity of the dementia process and frontal damage. Insight deficit seems to be more related to the topography of degenerative lesions than to the type of dementia and has predictive value to program more early and intensive ac- tions in order to minimize socio-functional limitations related to deficits in insight. Insight and Theory of Mind deficits seem to constitute markers of the pathophisiological process involved in the deterioration of the frontal lobe executive functions.

Many of the more representative FTD behaviors (egocentrism, lackness of social tact, apathy, several language disorders, paranoid delusions) may be understood as phenomenological manifestations related to Theory of Mind and insight deficits.

KEY WORDS: dementia, Alzheimer's disease, frontotemporal dementia, self-consciousness disturbances.

*Neurobiologia e fenomenologia dos distúrbios de auto-consciência na demência frontotemporal e na doença de Alzheimer (Resumo). Tese de Doutorado, Faculdade de Mediciana da Universidade de São Paulo (Área: Neurologia). Orientador: Ricardo Nitrini.

Address: Rua J 12 Quadra 115 Lote 5, Setor Jaó, 74674-280 Goiânia GO, Brasil.

\title{
DEVELOPMENT OF THE HUMAN CINGULATE CORTEX IN THE PERINATAL PERIOD: AN EXPERIMEN- TAL STUDY (ABSTRACT)*. THESIS. RIO DE JANEIRO, 2000.
}

\author{
LEONARDO C. DE AZEVEDO**
}

The development of the cerebral cortex in humans has seldom been the subject of experimental studies, for lack of appropriate techniques.

We approached this issue by associating modern postmortem tracing with histochemistry and immunohistochemistry, applied to the cingulate cortex $(\mathrm{CgC})$ of fetuses in the second half of gestation. (1) In order to identify developing callosal neurons in the $\mathrm{CgC}$, we inserted Dil crystals into the bisected midsagital callosal surface of fetuses at 25-32 weeks post-ovulatory (wpo). After 4-6 months, blocks of the $\mathrm{CgC}$ were cut and analysed under a fluorescence microscope. (2) In order to establish the nitridergic (NO - nitric oxide positive cells) phenotype of developing neurons of 18-35 wpo fetuses, sections were reacted histochemically for diaphorase. (3) In order to follow the development of radial glial cells (RGCs) in the $\mathrm{CgC}$ of fetuses at 24-40 wpo, we inserted Dil and DiA crystals into the pial and ventricular surfaces, and processed adjacent blocks for vimentin and GFAP.

Our results showed that: (1) callosal cells were detected in the transient subplate (SP) with differ- ent dendritic morphologies, indicating an advanced degree of differentiation; (2) many cingulate SP neurons were positive for diaphorase, with similar morphologies as callosal cells, suggesting that some of the latter may be nitridergic; (3) pially and ventricularly inserted Dil/DiA revealed RGCs were seen to detach first from the ventricular surface, starting their transformation into astrocytes; (4) RG fibers presented a depth-correlated morphology, being smooth at the cortical plate (CP), covered with varicosities and spines in the upper SP and progressively rougher close to the cell body, suggesting that this transitory layer and other local factors might be influencing glial transformation.

We concluded that the developing cingulate cortex in the perinatal period is the site of dynamic transformations of radial glial cells and contains transient neurons at the SP that display an unexpected hodological and neurochemical complexity.

KEY WORDS: human brain, cortical development, limbic system, corpus callosum, cortical plate, subplate, nitric oxide, radialglia, astrocytes.

\footnotetext{
*Desenvolvimento do córtex cerebral humano no período perinatal: um estudo experimental (Resumo). Tese de Doutorado, Instituto de Ciências Biomédicas da Universidade Federal do Rio de Janeiro / Pós-Graduação em Ciências Morfológicas (Área: Neurociências). Orientador: Roberto Lent.
} 


\title{
MOYAMOYA LIKE ARTERIOPATHY IN DOWN SYNDROME: META-ANALYSIS AND CLINICAL EPIDE- MIOLOGICAL STUDY (ABSTRACT)*. DISSERTATION. CAMPINAS, 2000.
}

\author{
PAULO ALVES JUNQUEIRA**
}

Patients diagnosed with Down syndrome and cerebrovascular abnormalities similar to those detected in moyamoya disease (moyamoya phenomenon) have been systematically described in the last 20 years.

This paper has the goal of studying two children diagnosed with Down syndrome who presented with an acute ischemic vascular condition, and were cared for at the Child Neurology Department of FMC UNICAMP, and reviewing the literature pertaining to this theme.

The patients were clinically and neurologically evaluated, imaging tests were performed and a meta-analysis was conducted including all the cases in the literature presenting the above association in the period of 1977 to 2000.

Forty cases reports were found plus two cases followed by the author. Nine were infants (up to two years of age ), nineteen pre-schoolers (2-6 years of age), six children in school age (7-12 years of age), five teen-agers (13-19 years of age) and only three adults (over 20 years of age). The gender ratio was 1:1.33 (male/female ratio). With regard to the disease subtype, the transient ischemic attack (TIA) type was reported in 7 patients $(16,6 \%)$, the infarction type in $32(76,2 \%)$, and the hemorrhagic type in 3 $(7,2 \%)$. The age of onset of signs and symptoms ranged from six months to 27 years of age, with a peak incidence occurring between one and six years
.The patients included in the meta-analysis came from 12 different countries, and of the total 13 came from Japan. Hemiparesis was initial clinical symptom in 33 cases $(78,5 \%)$, followed by speech disorders in 11 cases $(26,2 \%)$, seizures in 6 cases $(14,3 \%)$, and, with a lower incidence, from most to less frequent, involuntary movements (chorea), muscle weakness, facial paralysis, headache, optical atrophy and cortical blindness in the remaining cases. In 24 patients, at the time of diagnosis, there was only one neurological disorder present; in 15 patients, two concurrent disorders; and in 3 patients, three concurrent disorders. Vascular involvement was bilateral in 35 cases $(83.3 \%)$ and unilateral in 7 cases $(16.7 \%)$. Congenital heart defects were present in 10 patients $(23.8 \%)$, and among those, ventricular septal defect was the most frequent condition (40\%). Ischemic episodes were recurrent in 26 patients $(62 \%)$ and isolated in 16 (38\%).

These data highlight the frequent association between Down syndrome and moyamoya disease, so that, when faced with Down syndrome patients with acute hemiparesis episodes, the hypothesis should be raised of an ischemic vascular condition including moyamoya syndrome in the differential diagnosis.

KEY WORDS: cerebrovascular disorder, stroke, Down syndrome, moyamoya.

\footnotetext{
*Arteriopatia do tipo moyamoya na síndrome de Down: estudo clínico-epidemiológico através de metanálise (Resumo) . Dissertação de Mestrado, Faculdade de Ciências Médicas da Universidade de Campinas - UNICAMP (Área : Neurologia). Orientadora : Maria Valeriana Leme de Moura-Ribeiro.

**Address: Rua Mario Borin 500, 13209-030 Jundiaí SP, Brasil. E-mail: ppaj@terra.com.br
}

\section{CRITICAL EVALUATION OF THE DOSAGE OF LACTATE IN THE CEREBROSPINAL FLUID IN INFECTIOUS DISEASES OF THE CENTRAL NERVOUS SYSTEM. (ABSTRACT)*. DISSERTATION. SÃO PAULO, 2001.}

\author{
HIDERALDO LUÍS SOUZA CABEÇA**
}

This paper tries to critically analyze the diagnosis aid of the dosage of lactate in the cerebrospinal fluid (CSF) in infectious diseases of the central nervous system (CNS).

We analyzed in a prospective way 130 samples of CSF of 116 patients with diagnoses of infectious processes in the CNS. The 130 samples of CSF were divided into five groups: 28 samples of the control group, 40 of bacterial meningitis, 22 of viral meningitis, 16 of fungal meningitis and 24 of patients presenting Acquired Immune Deficiency Syndrome (AIDS). All samples were submitted to a global score 
of their number of cells; cytomorphologic test; basic biochemical test; dosage of lactic acid; general immunologic tests; microbiologic and mycologic tests as necessary; immunologic specific tests as indicated.

We determined average, standard deviation, median, minimal and maximum rates of each group for cellularity, total protein contents, glucose and lactate in the samples of CSF.

The concentration of lactate in the CSF was elevated in the group of patients with bacterial meningitis (average $=46,20 \mathrm{mg} / \mathrm{dL}$ ), fungal meningitis (average $=27,37 \mathrm{mg} / \mathrm{dL}$ ) and in the AIDS group (average $=23,54 \mathrm{mg} / \mathrm{dL}$ ). In the control group and viral meningitis group the lactate content in the CSF presented the reference rates according to the employed method. The groups analyzed were submitted to a paired study in order to avail the statistical significance of the variables as cellularity, total proteins, glucose and lactate in the CSF. The lactate dosage in the CSF presented a negative correlation with glycorrhachia and positive correlation with the cellularity and total proteins of the CSF.

We conclude that the lactate dosage in the CSF, although unspecified, helps to distinguish the infectious processes of the CNS.

KEY WORDS: lactate, cerebrospinal fluid, infectious diseases, AIDS.

* Avaliação crítica da dosagem de lactato no líquido cefalorraqueano em moléstias infecciosas do sistema nervoso central (Resumo) Dissertação de Mestrado. Faculdade de Medicina da Universidade de São Paulo (Área: Neurologia). Orientador: José Antonio Livramento.

** Address: Praça Amadeu Amaral 47 / 33, 01327-010 São Paulo SP, Brasil.

THESES é seção de Arquivos de Neuro-Psiquiatria que divulga os resumos em inglês de teses defendidas e aprovadas. $O$ assunto da tese deve estar relacionado a aspectos clínicos ou experimentais de interesse em neurologia, ciências a ela afins e psiquiatria. Para publicação, o Autor deve encaminhar ao Editor: abstract da tese, acompanhado do título em inglês e em português; key words; disquete com a reprodução desses dados.

Adicionalmente, o Autor deve informar: a natureza da tese (Dissertação/Tese de Mestrado, Tese de Doutorado, Tese de LivreDocência - como exemplos); nome da instituição na qual foi defendida e respectiva área de concentração; nome do Orientador, quando for o caso; endereço para correspondência. 